\title{
Aleksander Gadkowski
}

\section{Europejski Komitet Praw Społecznych w systemie organów traktatowych międzynarodowej ochrony praw człowieka}

\section{Wprowadzenie}

Dyskusja naukowa na temat międzynarodowej ochrony praw człowieka jest bardzo szeroka i wielowątkowa. Wynika to zwłaszcza z dynamiki rozwoju regulacji prawnych w tej dziedzinie oraz ze szczególnej wagi problematyki będącej przedmiotem tych regulacji. Stanowiąc bardzo ważną część współczesnego prawa międzynarodowego, międzynarodowe prawo praw człowieka wyraża bez wątpienia uniwersalne i ogólnoludzkie wartości o fundamentalnym znaczeniu. Jego ewolucja w ostatnich kilkudziesięciu latach oznaczała i oznacza rozwijanie oraz wzbogacanie tego systemu normatywnego o nowe prawa człowieka, nowe środki ich promocji, a przede wszystkim zinstytucjonalizowane i efektywne mechanizmy międzynarodowej kontroli. Spowodowała również, że uniwersalny system międzynarodowej ochrony praw człowieka w ramach Organizacji Narodów Zjednoczonych, którego podstawą pozostają Powszechna Deklaracja Praw Człowieka ${ }^{1}$, Międzynarodowe Pakty Praw Człowieka² i cały system konwencji Narodów Zjednoczonych, został w istotny sposób rozbudowany i wzbogacony o systemy regionalne - pomimo oczywistego uniwersalnego charakteru praw człowieka i podstawowych wolności można przytoczyć argumenty przemawiające za rozwijaniem regulacji regionalnych w tym

1 Tekst Deklaracji vid. A/RES/217(III); tekst polski vid. B. Gronowska, T. Jasudowicz, C. Mik, Prawa cztowieka. Dokumenty międzynarodowe, Toruń 1993, s. 18-24.

2 Międzynarodowy Pakt Praw Obywatelskich i Politycznych oraz Międzynarodowy Pakt Praw Gospodarczych, Społecznych i Kulturalnych; tekst polski vid. Dz. U. 1977, Nr 38, poz. 167 i 169. Pierwszy z Paktów wszedł w życie 23 marca 1976 r. (postanowienia dotyczące art. 41 weszły w życie 26 marca 1979 r.), tekst: UNTS 999:171 i 1057:407; aktualna liczba stron - 168 państw, data ratyfikacji przez Polskę: 18 marca 1977 r. Drugi z Paktów wszedł w życie 3 stycznia 1976 r., tekst: UNTS 999:3; aktualna liczba stron - 162 państw, data ratyfikacji przez Polskę: 18 marca 1977 r., na podstawie: http://treaties.un.org/. 
zakresie ${ }^{3}$. Mogą być one lepiej dostosowane do specyficznych uwarunkowań politycznych, ekonomicznych i społecznych w ramach danego regionu geograficznego. Ponadto, w ramach takiego regionu, $\mathrm{z}$ uwagi na naturalną niejako wspólnotę interesów i dorobek cywilizacyjny, można zbudować bardziej efektywny system kontrolny. Istotnego argumentu na rzecz rozwijania regionalnych systemów normatywnych $\mathrm{w}$ tym zakresie używa na przykład Tadeusz Jasudowicz, według którego dopóki uniwersalny system ochrony praw człowieka nie doczeka się głębokiej reformy, zwłaszcza w zakresie instrumentów kontrolnych, ,ciężar stopniowego urzeczywistniania wspomnianej idei będzie spoczywał na systemach regionalnych"4. Pomimo, że koncepcja regionalizmu w międzynarodowej ochronie praw człowieka była również poddawana krytyce jako pociągająca za sobą ryzyko osłabienia ochrony uniwersalnej oraz potencjalnej kolizji norm uniwersalnych z regionalnymi, to można postawić tezę, że w praktyce implementacji międzynarodowego prawa praw człowieka ochrona podstawowych praw i wolności jest silniejsza w systemach regionalnych, czego najlepszy przykład stanowi system Rady Europy ${ }^{5}$. W systemie tym znajdujemy wzorcowe dla regionalnych systemów międzynarodowej ochrony praw człowieka rozwiązania prawne i instytucjonalne oraz najbardziej efektywne mechanizmy kontrolne.

Rada Europy była pierwszą organizacją międzynarodową, która swoim fundamentem ustanowiła wartości wyraźnie nawiązujące do praw człowieka ${ }^{6}$. Analiza postanowień Statutu Rady Europy oraz jej dorobku normatywnego upoważnia do wyrażenia stanowiska, że żadna inna znacząca organizacja międzynarodowa nie została oparta tak mocno i jednoznacznie na przekonaniu o wadze praw człowieka. Już w preambule Statutu państwa-sygnatariusze wyraziły swoje głębokie przywiązanie do duchowych i moralnych wartości stanowiących wspólne dziedzictwo narodów i źródło zasad wolności osobistej, swobód politycznych i praworządności stanowiących podstawę każdej prawdziwej demokracji. Tak sformułowane postanowienia preambuły to ważny kontekst interpretacyjny dla art. 1 Statutu, który określa cele Rady Europy. W rozumieniu tego przepisu należy do nich: „osiągnięcie większej jedności między jej członkami, aby chronić i wcielać w życie ideały i zasady, stanowiące ich wspólne dziedzictwo, oraz aby ułatwić ich postęp ekonomiczny i społeczny". Należy podkreślić, że w procesie realizacji tego celu bardzo ważne miejsce zajmują prawa człowieka. Art. 1 pkt b Statutu stanowi bowiem, że: „Cel ten będzie urzeczywistniany za pośrednictwem organów

$3 \mathrm{Na}$ temat uniwersalności praw człowieka i krytyki tej koncepcji vid. K. Przybyszewski, Uniwersalnośc praw cztowieka pod ostrzatem krytyki, [w:] Prawa cztowieka. Wybrane zagadnienia i problemy, red. L. Koba, W. Wacławczyk, Warszawa 2009, s. 31 i n.

4 T. Jasudowicz et. al., Prawa cztowieka i ich ochrona. Podręcznik dla studentów prawa i administracji, Toruń 2005, s. 69.

5 Cf. ibidem, s. 79.

6 Np. P. Świtalski, Miejsce Rady Europy weuropejskiej architekturze instytucjonalnej, [w:] 60 lat Rady Europy. Tworzenie i stosowanie standardów prawnych, red. H. Machińska, Warszawa 2009, s. 15. 
Rady (...) przez przestrzeganie i rozwój praw człowieka i podstawowych wolności”7. Dodać należy, że ważne źródło systemu normatywnego Rady Europy w kontekście praw człowieka to także postanowienia art. 3 Statutu, które, nawiązując do zasady rule of law, głoszą, że: „Każdy członek Rady Europy uznaje zasadę praworządności oraz zasadę, iż wszystkie osoby pozostające pod jego jurysdykcją korzystają z praw człowieka i podstawowych wolności..."

Dorobek traktatowy Rady Europy w dziedzinie ochrony praw człowieka jest bardzo duży. Pośród ponad 200 konwencji i protokołów pierwszoplanowe miejsce zajmują regulacje normatywne w dziedzinie ochrony praw człowieka ${ }^{9}$. W działalności normatywnej Rady Europy w tej dziedzinie w pierwszych latach jej funkcjonowania wyraźna była tendencja do koncentrowania się na prawach obywatelskich i politycznych, które w według klasycznej koncepcji trzech generacji praw człowieka zaliczone zostały do pierwszej z nich ${ }^{10}$. Niewątpliwie najbardziej znaczącym osiągnięciem Rady Europy w tej dziedzinie było podpisanie 4 listopada 1950 roku w Rzymie Konwencji o Ochronie Praw Człowieka i Podstawowych Wolności ${ }^{11}$. Nie oznacza to oczywiście, że Rada Europy nie doceniała wagi i znaczenia praw człowieka zaliczanych do drugiej generacji, a zwłaszcza praw socjalnych ${ }^{12}$. Należy wyrazić przekonanie, że ich ranga była zawsze dla Rady ważna, o czym świadczy najlepiej sposób sformułowania klauzuli praw człowieka w postanowieniach statutu. Bez wątpienia jednak proces kodyfikacji praw człowieka w ramach Rady Europy przebiegał dwutorowo i według dwóch różnych prędkości: najpierw i szybciej kodyfikowano prawa obywatelskie i polityczne, a następnie prawa gospodarcze i społeczne, w tym socjalne. W literaturze, w której dla oznaczenia tych procesów przyjmuje się określenia: double-track i double-speed, panuje zasadniczo zgoda co do oceny tego procesu. Warto powołać w związku z tym stanowisko Krzysztofa Drzewieckiego, piszącego, że powody dwutorowości i podwójnej prędkości sięgają swoim rodowodem

7 Tekst Statutu Rady Europy vid. European Treaty Series (ETS) No 001 (tekst polski vid. Dz. U. z 1994 r., Nr 118, poz. 565).

8 A. Gadkowski, Problematyka klasyfikacji praw cztowieka na przyktadzie dorobku traktatowego Rady Europy, [w:] Gospodarka i Polityka w badaniach mtodych naukowców, red. W. Stach, Poznań 2013, s. 53 i n.

9 Dorobek traktatowy Rady Europy vid. http://www.conventions.coe.int/.

10 Najbardziej znana klasyfikacja praw człowieka w ramach koncepcji trzech generacji vid. K. Vasak, Le droit international des droits de l'homme, [w:] „Revue des Droits de l'Homme” t. I, 1972, s. 43 i n. oraz eadem, Pour les droits de l'homme de la troisième génération: les droits de solidarité. [w: „Leçon inaugurale. Dixième Session d'Enseignement”, Strasbourg 2-27 juillet 1979, s. 1-7; w literaturze polskiej vid. np. K. Drzewicki, Trzecia generacja praw cztowieka, [w:] „Sprawy Międzynarodowe" nr 10, 1983, s. 83 i n.

11 Tekst vid. ETS No. 005; (tekst polski: Dz. U. z 1993 r., Nr 61, poz. 285). Konwencja weszła w życie 3 września $1953 \mathrm{r}$.

12 O działalności Rady Europy w tej dziedzinie pisze np. P.-Y. Greber, Le Conseil de L'Europe et la sécurité sociale: réalisations et perspectives, [w:] Les droits de l'bomme et la constitution, red. A. Auer, A. Flückiger, M. Hottelier, Genewa 2007, s. 443 i n. 
krajowych regulacji prawnych w tej dziedzinie. Prawa obywatelskie i polityczne były już wcześniej stosunkowo dobrze rozwiniętymi standardami w ustawodawstwie różnych państw demokratycznych, zanim jeszcze doszło do prawdziwej internacjonalizacji praw człowieka. $Z$ drugiej zaś strony, prawa gospodarcze, społeczne i kulturalne, jako odrębna kategoria praw człowieka, stały się przedmiotem krajowych regulacji prawnych dopiero po II wojnie światowej, co niewątpliwie wpłynęło na opóźnienie procesu ich internacjonalizacji i kodyfikacji13.

Dorobek traktatowy Rady Europy w zakresie kodyfikacji praw człowieka drugiej generacji obejmuje regulacje normatywne określane zwykle jako system Europejskiej Karty Społecznej. System ten można postrzegać jako uzupełnienie bardziej znanego w strukturze Rady Europy systemu Konwencji o Ochronie Praw Człowieka i Podstawowych Wolności. Karta uzupełnia bowiem wcześniejszą Konwencję o Ochronie Praw Człowieka i Podstawowych Wolności, co oznacza kompleksowe uregulowanie tej kwestii w systemie Rady Europy ${ }^{14}$. Konwencja ta, podpisana 4 listopada 1950 roku, a inspirowana bez wątpienia Powszechną Deklaracją Praw Człowieka, stanowi wraz z protokołami dodatkowymi najbardziej zaawansowany system regionalnej ochrony praw człowieka, dysponujący środkami efektywnej kontroli międzynarodowej, włącznie z procedurami sądowymi w ramach Europejskiego Trybunału Praw Człowieka ${ }^{15}$.

Na system Europejskiej Karty Społecznej składają się:

- Europejska Karta Społeczna podpisana w Turynie 18 października 1961 roku. Weszła w życie 26 lutego $1965 \mathrm{roku}^{16}$. Jej stronami jest aktualnie 27 państw członkowskich Rady Europy ${ }^{17}$. Polska ratyfikowała Kartę 25 czerwca 1997 roku, gdzie weszła w życie 25 lipca 1997 roku $^{18}$.

- Protokół Dodatkowy, podpisany 5 maja 1988 roku. Wszedł w życie 4 września $1992 \mathrm{roku}^{19}$. Został przyjęty w następstwie wcześniejszego uchwalenia przez Radę Europy Deklaracji o Prawach Człowieka z 27 kwietnia 1978 roku $^{20}$. Jego stronami

13 K. Drzewicki, Prawa socjalne w Radzie Europy, [w:] Polska i Rada Europy 1999-2002, red. H. Machińska, Warszawa 2005,s. 138.

14 Uzasadnienie vid. R. Brillat, La Charte sociale européenne du Conseil de l'Europe: Développements récents, [w:] „Droit en Quart Monde” nr 12, 1996, s. 37.

15 Tekst polski vid. Dz. U. z 1993 r., Nr 61, poz. 285. W stosunku do Polski Konwencja weszła w życie 19 stycznia 1993 r. Natomiast 1 maja 1993 r. weszły w życie w stosunku do Polski dwie deklaracje uznające kompetencje Europejskiego Trybunału Praw Człowieka. Literatura na temat Konwencji jest bardzo bogata; vid. np. M. A. Nowicki, Wokót Konwencji Europejskiej, Warszawa 2009.

16 Tekst Karty vid. ETS No. 035.

17 Conseil de l'Europe, Bureau des Traités, http://www.conventions.coe.int/.

18 Tekst polski vid. Dz. U. z 1999 r., Nr 8, poz. 67. Analiza postanowień Karty patrz np. A. Świątkowski, Prawo socjalne Rady Europy, Kraków 2006, s. 12 i nast.

19 Tekst Protokołu vid. ETS No. 128.

20 Pisze o tym A. Świątkowski: Karty Spoteczne Rady Europy, [w:] „Państwo i Prawo” nr 8, 2003, s. 38. 
jest aktualnie 13 państw członkowskich Rady Europy ${ }^{21}$. Polska dotychczas nie ratyfikowała tego Protokołu.

- Protokół Zmieniający podpisany w Turynie 21 października 1991 roku, w 30 rocznicę podpisania samej Karty ${ }^{22}$. Protokół ten nie wszedł jeszcze w życie ${ }^{23}$.

- Protokół Dodatkowy podpisany w Strasburgu 9 listopada 1995 roku. Wszedł w życie 1 lipca 1998 roku$^{24}$. Jego stronami jest aktualnie 13 państw członkowskich Rady Europy $^{25}$. Polska dotychczas nie ratyfikowała tego Protokołu.

- Zrewidowana Europejska Karta Społeczna podpisana w Strasburgu 3 maja 1996 roku, Weszła w życie 1 lipca 1997 roku $^{26}$. Jej stronami jest aktualnie 33 państw członkowskich Rady Europy ${ }^{27}$. Polska dotychczas nie ratyfikowała Karty.

System Europejskiej Karty Społecznej uzupełniają pozostające z nim w ścisłym związku:

- Europejski Kodeks Zabezpieczenia Społecznego podpisany 16 kwietnia 1964 roku $^{28}$, opracowany przy udziale Międzynarodowej Organizacji Pracy, a zrewidowany 6 listopada 1990 roku$^{29}$;

- Konwencja o Zabezpieczeniu Społecznym podpisana 14 grudnia 1972 roku $^{30}$;

- Konwencja o Pomocy Społecznej i Medycznej podpisana 11 grudnia 1953 roku³;

- Konwencja o statusie prawnym pracowników migrujących podpisana 24 listopada $1977 \mathrm{roku}^{32}$.

W systemie normatywnym Europejskiej Karty Społecznej znajdujemy nie tylko obszerny katalog praw człowieka zaliczanych do praw człowieka drugiej generacji, ale również mechanizm kontrolny, w ramach którego szczególna role odgrywa Europejski Komitet Praw Społecznych - jeden z organów traktatowych w dziedzinie międzynarodowej ochrony praw człowieka.

21 Conseil de l'Europe, Bureau des Traités, http://www.conventions.coe.int/.

22 Tekst Protokołu vid. ETS No. 142.

23 Aktualnie stronami tego protokołu są 23 państwa-strony Europejskiej Karty Społecznej. Do wejścia w życie konieczne są, zgodnie z postanowieniami art. 8, ratyfikacje wszystkich państw-stron Karty. Polska ratyfikowała Protokół 25 czerwca 1997 r. (tekst polski vid. Dz. U. z 1999 r., $\mathrm{Nr}$ 8, poz. 67).

24 Tekst Protokołu vid. ETS No. 158.

25 Conseil de l'Europe, Bureau des Traités, http://www.conventions.coe.int/.

26 Tekst Karty vid. ETS No.163.

27 Conseil de l'Europe, Bureau des Traités, http://www.conventions.coe.int/.

28 Wszedł w życie 17 marca 1968 r., tekst vid. ETS No. 048. Polska nie jest jego stroną.

29 Do tej pory nie wszedł w życie, tekst vid. ETS No. 139. Polska nie jest jego stroną.

30 Weszła w życie 1 marca 1977 r., tekst vid. ETS No. 078. Polska nie jest jej stroną.

31 Weszła w życie 1 lipca 1954 r., tekst vid. ETS No. 014. Polska nie jest jej stroną.

32 Weszła w życie 1 maja 1983 r., tekst vid. ETS No. 093. Polska nie jest jej stroną. 
76 | Adam Mickiewicz University Law Review

\section{Organy traktatowe w procesie implementacji norm międzynarodowego prawa praw czlowieka w systemie ONZ}

\section{Uwagi ogólne}

Nie ulega żadnej wątpliwości, że efektywność regulacji prawnych międzynarodowego prawa praw człowieka zależy przede wszystkim od jakości i skuteczności określonych w nich instytucji i mechanizmów kontrolnych. Taki mechanizm kontrolny funkcjonuje również w systemie Europejskiej Karty Społecznej. Zostanie zaprezentowany na tle ogólnych uwag na temat innych systemów kontrolnych, jakie znajdujemy zwłaszcza w systemie międzynarodowej ochrony praw człowieka o charakterze uniwersalnym funkcjonującym w ramach ONZ. Oparto go na dwóch filarach.

Pierwszy z nich autorzy określają zwykle mianem systemu politycznego. Nawiązuje do Karty Narodów Zjednoczonych. Organem kontrolnym jest tu Rada Praw Człowieka, która w 2006 roku zastąpiła działającą od 1946 roku Komisję Praw Człowieka i która, podobnie jak Komisja, stanowi organ pomocniczy Ogólnego Zgromadzenia ${ }^{33}$. Rada ma swoją siedzibę w Genewie i składa się z 47 członków wybieranych przez Ogólne Zgromadzenie według klucza geograficznego oraz oceny osiągnięć państw w dziedzinie propagowania i ochrony praw człowieka ${ }^{34}$. Oprócz działalności na rzecz szeroko pojmowanej promocji praw człowieka oraz dialogu i współpracy w tej dziedzinie, Rada realizuje szczególowe zadania, określone w pkt. 5 powołującej ją do życia rezolucji Ogólnego Zgromadzenia. Należą do nich między innymi: przedstawianie na forum Ogólnego Zgromadzenia rekomendacji dalszego rozwoju międzynarodowego prawa praw człowieka oraz wspieranie realizacji zobowiązań podjętych przez państwa w zakresie przestrzegania praw człowieka. Rada przejęła wcześniejszy system specjalnych procedur kontrolnych stosowanych w czasie działalności Komisji Praw Człowieka, a także dysponuje nowym mechanizmem w tej dziedzinie, czyli mechanizmem powszechnych, okresowych przeglądów, którymi objęte są wszystkie państwa członkowskie ONZ. Przeglądy takie mają charakter uzupełniający do procedur funkcjonujących już w ramach działalności organów traktatowych, a niewątpliwym pozytywnym skutkiem ich uruchomienia jest stworzenie kolejnego, ważnego forum rozmów o prawach człowieka zarówno w ramach całej społeczności międzynarodowej, jak również w poszczególnych państwach ${ }^{35} . \mathrm{Na}$

33 Rezolucję A/RES/60/251 o utworzeniu Rady Praw Człowieka Zgromadzenie Ogólne ONZ uchwaliło 15 marca $2006 \mathrm{r}$.

34 Polska została wybrana do pierwszego składu Rady w 2006 r.; ta pierwsza kadencja Polski została w drodze losowania określona na rok. Kolejna kadencja Polski w Radzie upłynęła z końcem $2013 \mathrm{r}$. Warto podkreślić, że rotacyjne roczne przewodnictwo w Radzie sprawowała w $2013 \mathrm{r}$. Polska (Ambasador - Stały Przedstawiciel RP przy Biurze ONZ w Genewie - R. A. Henczel).

35 Spośród bogatej już literatury na temat Rady Praw Człowieka vid. np. A. Bieńczyk-Missala, Rada Praw Cztowieka ONZ - wyzwanie dla polskiejpolityki zagranicznej, [w:] „Polski Przegląd Dyplomatyczny" nr 4, 2006, s. 33-47; R. Wieruszewski, Reforma systemu ochrony praw cztowieka 
przykład sprawozdanie Polski było przedmiotem dyskusji w czasie pierwszego okresowego przeglądu dokonanego przez Grupę Roboczą Rady Praw Człowieka do Spraw Okresowego Przeglądu na 1 sesji w terminie 7-18 kwietnia 2008 roku, a kolejne w czasie przeglądu dokonywanego przez Grupę na jej 13 sesji w terminie od 21 maja do 4 czerwca $2012 \mathrm{roku}^{36}$.

Drugi filar, określany mianem prawnego lub traktatowego, tworzą organy kontrolne powołane w ramach systemów traktatowych uchwalonych pod egidą Organizacji Narodów Zjednoczonych ${ }^{37}$. Poszczególne organy traktatowe w zakresie ochrony praw człowieka działające $\mathrm{w}$ ramach $\mathrm{ONZ}$ przewidziane są w następujących umowach międzynarodowych:

- Międzynarodowy Pakt Praw Obywatelskich i Politycznych z 16 grudnia 1966 roku, (organ traktatowy: Komitet Praw Człowieka - CCPR).

- Międzynarodowy Pakt Praw Gospodarczych, Społecznych i Kulturalnych z 16 grudnia 1966 roku, (organ traktatowy: Komitet Praw Gospodarczych, Społecznych i Kulturalnych - CESCR).

- Konwencja w sprawie eliminacji wszelkich form dyskryminacji rasowej z 7 marca 1966 roku, (organ traktatowy: Komitet do Spraw Eliminacji Dyskryminacji Rasowej - CERD $)^{38}$.

- Konwencja w sprawie eliminacji wszelkich form dyskryminacji kobiet z 18 grudnia 1979 roku, (organ traktatowy: Komitet do Spraw Likwidacji Dyskryminacji Kobiet - CEDAW) $)^{39}$.

- Konwencja przeciwko torturom i innemu okrutnemu, nieludzkiemu lub poniżającemu traktowaniu lub karaniu z 10 grudnia 1984 roku, (organ traktatowy: Komitet Przeciwko Torturom - CAT) ${ }^{40}$. W związku z wejściem w życie 22 czerwca 2006 roku Protokołu Fakultatywnego do tej Konwencji, podpisanego 18 grudnia 2002 roku, utworzony został Podkomitet Zapobiegania Torturom - SPT ${ }^{41}$.

- Konwencja o Prawach Dziecka z 20 listopada 1989 roku, (organ traktatowy: Komitet Praw Dziecka - CRC) ${ }^{42}$.

ONZ - Rada Praw Cztowieka, [w:] „Biuletyn PISM” nr 94, 2005, s. 1 i n. oraz H. Upton, The Human Rights Council: First Impressions and Future Challenges, [w:] „Human Rights Law Review" vol. 7, 2007, s. 29-39.

36 Sprawozdania Polski patrz dokumenty Rady: A/HRC/WG.6/1/POL/1 oraz A/HRC/ WG.6/13/POL/1.

37 Szerzej vid.np. R. Wieruszewski, ONZ-owski system ochrony praw cztowieka, [w:] B. Banaszak, A. Bisztyga, K. Complak, M. Jabłoński, R. Wieruszewski,. K. Wojtowicz, System ochrony praw cztowieka, Kraków 2005, s. 61 i n.

38 Tekst Konwencji: UNTS 660:195.

39 Tekst Konwencji: UNTS 1249:13.

40 Tekst Konwencji: UNTS 1465:85.

41 Tekst Protokołu: UNTS 2375:237.

42 Tekst Konwencji: UNTS 1577:3. 
- Konwencja o ochronie praw wszystkich pracowników migrujących i ich rodzin z 18 grudnia 1990 roku, (organ traktatowy: Komitet do Spraw Pracowników Migrujących - CMW) ${ }^{43}$.

- Konwencja o Prawach Osób Niepełnosprawnych z 30 marca 2006 roku, (organ traktatowy: Komitet Praw Osób Niepełnosprawnych - CRPD).

- Konwencja o ochronie wszystkich osób przed wymuszonym zaginięciem z 20 grudnia 2006 roku, (organ traktatowy: Komitet do Spraw Wymuszonych Zaginięć - CED) ${ }^{44}$.

Należy w związku z tym zauważyć, że liczba traktatów w ramach uniwersalnego systemu międzynarodowej ochrony praw człowieka jest znacznie większa. Jak podkreśla jednak Roman Wieruszewski, tylko w ramach wyżej wymienionych umów przyjętych w ramach Narodów Zjednoczonych ukształtowane zostały organy kontrolne, powszechnie określane jako organy traktatowe, mające nadzorować realizację ich postanowień. Do podstawowych celów działania organów traktatowych zalicza on zwłaszcza:

a. promocję szeroko rozumianej kultury praw człowieka,

b. interpretacje traktatów międzynarodowego prawa praw człowieka, zwłaszcza poprzez system sprawozdań i skarg,

c. wskazywanie na kluczowe problemy implementacji traktatów poprzez przyjmowanie ogólnych komentarzy i rekomendacji,

d. udzielanie pomocy państwom-stronom traktatów w identyfikacji naruszeń praw człowieka oraz w poszukiwaniu sposobów poprawy tej sytuacji poprzez dialog z państwami i formułowanie uwag końcowych,

e. tworzenie ofiarom naruszeń praw człowieka platformy dochodzenia ich praw,

f. informowanie międzynarodowej opinii publicznej o sytuacji w dziedzinie praw człowieka i mobilizowanie jej do przeciwdziałania zagrożeniom w tym zakresie ${ }^{45}$.

\section{Organy traktatowe w systemie Międzynarodowych Paktów Praw Czlowieka}

W procesie implementacji postanowień Międzynarodowych Paktów Praw Człowieka funkcjonują dwa organy traktatowe: Komitet Praw Człowieka (CCPR) i Komitet Praw Gospodarczych, Społecznych i Kulturalnych (CESCR).

W literaturze podkreśla się, że spośród wszystkich organów traktatowych zdecydowanie najbogatsze doświadczenie, zwłaszcza w procesie rozpatrywania skarg indywi-

43 Tekst Konwencji: UNTS 2220:3.

44 Tekst Konwencji: Doc. A/61/488.

45 R. Wieruszewski, op. cit., s. 82. 
dualnych, ma Komitet Praw Człowieka ${ }^{46}$. Był on, obok Komitetu do Spraw Dyskryminacji Rasowej, pierwszym organem traktatowym o charakterze uniwersalnym, któremu powierzono monitorowanie przestrzegania praw człowieka. Podstawę prawną funkcjonowania Komitetu stanowią postanowienia części IV Międzynarodowego Paktu Praw Obywatelskich i Politycznych, jednakże z wyłączeniem instytucji skargi indywidualnej, której dotyczą postanowienia I Protokołu Fakultatywnego uchwalonego razem z Paktem, a który wszedł w życie 23 marca $1976 \mathrm{roku}^{47}$. Na podstawie postanowień art. 28 Paktu państwa-strony 28 września 1976 roku powołały do życia Komitet Praw Człowieka, jego kadencja rozpoczęła się formalnie 1 stycznia 1977 roku.

Kompetencje Komitetu jako organu traktatowego w dziedzinie ochrony praw człowieka obejmują: rozpatrywanie sprawozdań składanych przez państwa na podstawie art. 40 Paktu, rozpatrywanie skarg indywidualnych (zawiadomień indywidualnych), składanych na podstawie wskazanego wyżej I Protokołu Fakultatywnego, a stanowiących realizację tak zwanego prawa petycji do organu międzynarodowego oraz rozpatrywanie skarg międzypaństwowych składanych na podstawie art. $41 \mathrm{Paktu}^{48}$.Jak pisze Wieruszewski, który był jednym z osiemnastu członków Komitetu w latach: 1998-2000 oraz 2003-2006, ta ostatnia skarga „pozostała martwą literą, ponieważ ma zwykle polityczny charakter, a nadto została ukształtowana w sposób, który daje znikome szanse na skuteczne jej rozstrzygnięcie co do meritum" ${ }^{49}$. Jak wskazano wcześniej, jurysdykcja Komitetu odnośnie do rozpatrywania skarg indywidualnych zależy od ratyfikacji przez państwo-stronę Paktu I Protokołu Fakultatywnego. Z racji członkostwa w Radzie Europy szereg państw, w tym również Polska, złożyło jednak zastrzeżenie, oznaczające wyłączenie jurysdykcji Komitetu do przyjmowania skarg indywidualnych, gdy sprawa została już poddana pod „inną procedurę międzynarodowego badania lub rozstrzygnięcia”, co oczywiście obejmuje rozstrzygnięcie sprawy przez Europejski Trybunał Praw Człowieka. Zastrzeżenia te pozostają w związku z Rezolucją Komitetu Rady Ministrów Rady Europy z 15 maja 1970 roku, zalecającej państwom członkowskim Rady korzystanie w pierwszym rzędzie z procedury skargowej przewidzianej w art. 33 Konwencji o Ochronie Praw Człowieka i Podstawowych Wolności ${ }^{50}$. Ważną rolę w działalności Komitetu odgrywają nadto

46 Spośród publikacji na temat Komitetu vid. zwłaszcza: A. Michalska, Komitet Praw Cztowieka. Kompetencje, funkcjonowanie, orzecznictwo, Warszawa 1994 oraz R. Wieruszewski, A. Gliszczyńska, K. Sękowska-Kozłowska, Komitet Praw Człowieka. Wybór orzecznictwa, Warszawa 2009.

47 Tekst Protokołu vid. UNTS 999:171. Aktualnie stronami Protokołu jest 115 państw (stan na dzień 31/12/2013, na podstawie: http://treaties.un.org). Polska ratyfikowała ten Protokół 7 listopada 1991 r., a wszedł on dla Polski w życie 7 lutego 1992 r., tekst vid. Dz. U. z 1994 r., Nr 23, poz. 80 .

48 Skargi indywidualne i międzypaństwowe - w terminologii angielskiej: Individual Communications and Inter-State Complaints.

49 R. Wieruszewski, A. Gliszczyńska, K. Sękowska-Kozłowska, op. cit., s. 11.

50 Rezolucja nr 70 (17), która formalnie dotyczy skarg międzypaństwowych, a nie indywidualnych. 
komentarze ogólne, w których prezentuje on swoją interpretację poszczególnych norm Paktu w oparciu o realizowaną praktykę wynikającą zarówno z rozpatrywania sprawozdań państw-stron, jak również skarg indywidualnych ${ }^{51}$.

Kompetencje Komitetu w zakresie rozpatrywania skarg indywidualnych i międzypaństwowych, a zwłaszcza procedura rozpatrywania takich skarg powoduje, że w opinii niektórych autorów zasługuje on na miano organu quasi-sądowego ${ }^{52}$. Postępowanie skargowe może zakończyć się decyzją o uznaniu skargi za niedopuszczalną lub decyzją o umorzeniu postępowania na przykład z uwagi na fakt, że skarga została wycofana. W innych przypadkach Komitet Praw Człowieka, po merytorycznym rozpatrzeniu zaprezentowanych w skardze zarzutów, rozstrzyga, czy doszło do naruszenia postanowień Paktu. Organ ten nie wydaje jednak wyroku, a formułuje opinię $e^{53}$. Pomimo, że z formalnego punktu widzenia państwa nie są zobowiązane do uznania opinii Komitetu, skarga indywidualna do CCPR jest oceniana jako bardzo wartościowy środek ochrony praw człowieka w systemie ONZ ${ }^{54}$.

Drugi organ traktatowy w systemie Międzynarodowych Paktów Praw Człowieka, a więc Komitet Praw Gospodarczych, Społecznych i Kulturalnych, nie został jednak ustanowiony bezpośrednio w postanowieniach Międzynarodowego Paktu Praw Gospodarczych, Społecznych i Kulturalnych. Między innymi z uwagi na podniesioną wyżej specyfikę zobowiązań przewidzianych w tym Pakcie, państwom nie udało się osiągnąć porozumienia w tej sprawie. W części IV Paktu (art. 16-22) znalazły się jedynie postanowienia przewidujące obowiązek składania przez państwa-strony sprawozdań dotyczących podjętych środków oraz postępu dokonywanego w zakresie przestrzegania praw uznanych w Pakcie, jak również określające kompetencje Generalnego Sekretarza i Rady Gospodarczej i Społecznej, która mogła korzystać z pomocy organizacji wyspecjalizowanych oraz Komisji Praw Człowieka. W treści Paktu nie ma jednak żadnych postanowień kreujących zinstytucjonalizowany i skuteczny system monitorowania jego stosowania w praktyce, gdzie pierwszoplanową rolę odgrywałby odpowiedni organ traktatowy.

Komitet Praw Gospodarczych, Społecznych i Kulturalnych ustanowiono na mocy postanowień rezolucji Rady Gospodarczej i Społecznej ONZ z dnia 28 maja 1985 roku ${ }^{55}$. Fakt, że został on powołany na podstawie postanowień innych niż umowa międzynarodowa nie ma większego praktycznego znaczenia i CESCR jest powszechnie zalicza-

51 Pełna informacja o Komitecie i jego pracach vid. http://www.ohchr.org.

52 Vid. R. Wieruszewski, op. cit., s.10.

53 Problematykę tę szczegółowo przedstawia J. Rezmer, Jak korzystać z procedur skargowych w traktatowym systemie ochrony praw cztowieka ONZ?, Warszawa 2011, s. 16 i n. Vid. CCPR Rules of Procedure: CCCR/C/3/Rev.10 z 11 stycznia 2012 r.

54 Takie stanowisko prezentuje np. M. Balcerzak, Procedury ochrony praw cztowieka $i$ kontroli wykonywania zobowiazań przez państwa, [w:] B. Gronowska, T. Jasudowicz, M. Balcerzak, M. Lubiszewski, R. Mizerski, Prawa cztowieka i ich ochrona, Torun 2010, s. 168.

55 ECOSOC Res. 1985/17. 
ny do organów traktatowych w dziedzinie międzynarodowej ochrony praw człowieka w systemie ONZ. Pierwsza sesja Komitetu odbyła się w 1987 i obraduje on każdego roku w Genewie podczas dwóch trzytygodniowych sesji, według postanowień regulaminu z 1990 i 1993 roku $^{56}$. W skład Komitetu wchodzi 18 ekspertów wybieranych przez $\mathrm{ECOSOC}^{57}$.

Kompetencje Komitetu sprowadzają się aktualnie do analizy i oceny sprawozdań państw-stron Paktu, składanych zgodnie z postanowieniami art. 16 i 17, jako sprawozdania początkowe (składane w ciągu dwóch lat od ratyfikacji Paktu) oraz okresowe (składane przez państwa-strony co pięć lat) ${ }^{58}$. Komitet opracowuje ponadto tak zwane General Comments odnośnie do wybranych zagadnień będących przedmiotem regulacji Paktu ${ }^{59}$. Za bardzo interesującą inicjatywę Komitetu można uznać wprowadzenie dni ogólnej debaty (General Discussion Days) z udziałem członków Komitetu, przedstawicieli państw, organizacji pozarządowych, organizacji wyspecjalizowanych i ekspertów. Omawiane są wówczas szczególnie ważne problemy wynikające z działalności Komitetu. Ponadto Komitet organizuje misje do wybranych państw, w celu udzielenia im pomocy w tworzeniu odpowiednich warunków do lepszej realizacji postanowień Paktu ${ }^{60}$.

Istotne rozszerzenie kompetencji Komitetu nastąpiło po wejściu w życie Protokołu Fakultatywnego do Międzynarodowego Paktu Praw Gospodarczych, Społecznych i Kulturalnych. Został on uchwalony przez Ogólne Zgromadzenie 10 grudnia 2008 roku $^{61}$. Przewiduje on w art. 1 i następnych możliwość składania przez jednostki bądź $\mathrm{w}$ ich imieniu skarg indywidualnych (Individual Communications) i rozpatrywania ich przez Komitet. Protokół ten wszedł w życie w dniu 5 maja 2013 roku po uzyskaniu 10 wymaganych ratyfikacji ${ }^{62}$.

\section{Inne organy traktatowe w systemie ONZ}

Poza Komitetem Praw Człowieka oraz Komitetem Praw Gospodarczych, Społecznych i Kulturalnych, które funkcjonują w systemie Międzynarodowych Paktów Praw

56 CESCR Rules of Procedure: E/C.12/1990/4/Rev.1 z 1 marca 1993 r.

57 Polskim członkiem Komitetu Praw Gospodarczych, Społecznych i Kulturalnych jest Z. Kędzia, aktualnie Przewodniczący Komitetu. Wcześniej członkiem Komitetu był A. Rzepliński, aktualny Prezes Trybunału Konstytucyjnego.

58 Ostatnie sprawozdania Polski były przedmiotem dyskusji na sesjach Komitetu w 2002 r. (11-29 listopada) i w 2009 r. (2-20 listopada).

59 General Comments: np. "Right of everyone to take part in cultural life"(2009). Pełna informacja o Komitecie i jego pracach vid. http://www.ohchr.org/en/hrbodies/cescr/.

60 Pisze o tym np. R. Wieruszewski, op. cit., s. 89.

61 Tekst Protokołu vid. A/RES/63/117.

62 Polska nie ratyfikowała Protokołu; nie jest też jego sygnatariuszem. 
Człowieka, do organów traktatowych międzynarodowej ochrony praw człowieka działających w systemie ONZ należy siedem wymienionych wyżej Komitetów i jeden Podkomitet. Szczegółowe omawianie ich składu, kompetencji i praktycznej działalności nie jest konieczne w kontekście tego artykułu. $Z$ tego względu sformułowanych zostanie jedynie kilka uwag o charakterze bardziej ogólnym, odnoszących się zwłaszcza do wykorzystywanych przez te organy środków kontrolnych. Uwagi te będą przydatne przy szczegółowym prezentowaniu problematyki funkcjonowania systemu kontrolnego Europejskiej Karty Społecznej, w którym najważniejsze miejsce zajmuje również organ traktatowy - Europejski Komitet Praw Społecznych.

W przypadku wszystkich organów traktatowych ONZ, funkcjonujących na podstawie szczegółowych konwencji międzynarodowego prawa praw człowieka, wykorzystywana jest instytucja sprawozdań państw-stron przekazywanych poszczególnym organom traktatowym. Taka procedura kontrolna polega na sporządzaniu przez państwa sprawozdań (początkowych i okresowych) z wykonywania zobowiązań przewidzianych w postanowieniach danego traktatu i przesłania go do odpowiedniego organu kontrolnego. Sprawozdania takie badane są przez organ traktatowy, a w dyskusji nad nimi udział biorą również przedstawiciele zainteresowanych państw. Ocena sprawozdań przez organy traktatowe przybiera najczęściej postać uwag końcowych, w których formułowane są określone zalecenia pod adresem władz państwowych. System sprawozdań występuje w procedurze kontrolnej wszystkich organów traktatowych, ponieważ jego skuteczność opiera się przede wszystkim na dobrej woli państw, a możliwości „dyscyplinowania” państw przez organy traktatowe są w tym wypadku czysto iluzoryczne. Nie oznacza to jednak, że organy traktatowe należy uznawać za wyłącznie biernych adresatów przekazywanych pod ich adresem informacji ${ }^{63}$.

Zwracając uwagę na słabości systemu sprawozdań Wieruszewski prezentuje następujące dane statystyczne:

- około 70\% państw-stron każdego traktatu z zakresu międzynarodowej ochrony praw człowieka zalega ze składaniem sprawozdań,

- około $25 \%$ państw-stron zalega z pierwszymi raportami,

- łącznie mamy ponad 1200 zaległych sprawozdań, w sytuacji gdy organy traktatowe rozpatrzyły około 166 sprawozdań,

- niektóre organy traktatowe mają ponad dwuletnią zwłokę w rozpatrywaniu złożonych przez państwa sprawozdań ${ }^{64}$.

Zdecydowanie inaczej wygląda procedura stosowania skargi indywidualnej, adresowanej do organów traktatowych. Mechanizm ten pozwala uprawnionym podmiotom na składanie skarg na naruszenie przez państwo i jego organy postanowień określonego

63 Sprawozdania przekazywane przez Polskę organom traktatowym w ramach poszczególnych konwencji międzynarodowego prawa praw człowieka vid. www.msz.gov.pl.

64 R. Wieruszewski, ONZ-owski system..., op. cit., s. 98. 
traktatu. Skargi takie są zwykle określane jako zawiadomienia - Individual Communications, a podmiotami uprawnionymi do ich składania mogą być jednostki, grupy jednostek czy instytucje. Wskazano już, że możliwość składania takich skarg i ich rozpatrywania przez organy międzynarodowe stanowi realizację prawa petycji, oznaczającego możliwość skutecznego występowania osoby fizycznej w stosunkach międzynarodowych. W doktrynie prawa międzynarodowego jest to argument uzasadniający w określonym zakresie i proporcjach podmiotowość prawnomiędzynarodową osoby fizycznej ${ }^{65}$. Niewątpliwe jest więc znaczenie instytucji skarg indywidualnych w procesie implementacji norm międzynarodowego prawa praw człowieka, zarówno w wymiarze podmiotowym, jak i przedmiotowym. Kompetencje większości organów traktatowych, przyjmujących i rozpatrujących skargi indywidualne są uzależnione od zgody danego państwa-strony, wyrażanej zwykle poprzez ratyfikację odpowiedniego protokołu fakultatywnego. Zasygnalizowano zagadnienie wcześniej, wskazując na kompetencje CCPR do rozpatrywania skarg indywidualnych na podstawie postanowień I Protokołu Fakultatywnego do Międzynarodowego Paktu Praw Obywatelskich i Politycznych, jak również na podobne kompetencje CESCR na podstawie Protokołu Fakultatywnego do Międzynarodowego Paktu Praw Gospodarczych, Społecznych i Kulturalnych z 2008 roku. Podobne protokoły przewidziane są w postanowieniach innych konwencji, np. w art. 17 Konwencji w sprawie eliminacji wszelkich form dyskryminacji kobiet (CEDAW) oraz art. 34 Konwencji o prawach osób niepełnosprawnych (CRPD). Natomiast kompetencje CERD w tym zakresie oparte są na deklaracjach państw określonych w postanowieniach art. 14 Konwencji w sprawie eliminacji wszelkich form dyskryminacji rasowej, kompetencje CAT z kolei na podobnych deklaracjach określonych w postanowieniach art. 22 Konwencji przeciwko torturom i innemu okrutnemu, nieludzkiemu lub poniżającemu traktowaniu lub karaniu, a kompetencje CMW na deklaracjach określonych w postanowieniach art. 77 Konwencji o ochronie praw wszystkich pracowników migrujących $\mathrm{i}$ ich rodzin. Należy przy tym pamiętać, że żaden $\mathrm{z}$ tych organów traktatowych nie pełni funkcji sądowych, a ich orzeczenia przyjmowane na podstawie skarg, określane zwykle jako opinie i z formalnoprawnego punktu widzenia nie mają mocy wiążącej. Bez wątpienia jednak stanowią orzecznictwo jako case law, stąd częste nazywanie tych organów organami quasi-sądowymi ${ }^{66}$.

Niektóre wskazane wyżej traktaty międzynarodowego prawa praw człowieka przewidują również instytucję skarg międzypaństwowych i kompetencje organów traktatowych w tym zakresie. Jest to więc sytuacja, w której państwo-strona danego traktatu może tą drogą oskarżyć inne państwo-stronę o naruszenie określonego zobowiązania traktatowego. Procedura składania takich skarg przewidziana została obligatoryjnie w CERD, a fa-

65 Vid.np. R. Bierzanek, J. Symonides, Prawo międzynarodowe publiczne, Warszawa 2002, s. 137. 66 Ocenę funkcjonowania systemu skarg indywidualnych formułuje R. Wieruszewski, op. cit., s. 106-111. 
kultatywnie - a więc za dodatkową zgodą państw - w CAT i CMW. W praktyce funkcjonowania tych organów traktatowych, podobnie zresztą jak w zasygnalizowanym wyżej przypadku CCPR, mechanizm skargi międzypaństwowej jest martwy. Przesądzają o tym zwykle względy natury politycznej, a zwłaszcza obawa potencjalnych skarżących państw przed pogorszeniem wzajemnych politycznych i gospodarczych relacji z potencjalnym „oskarżonym”. Warto pamiętać przy tym o innych, ciekawych konstrukcjach prawnych przewidzianych w niektórych traktatach. Na przykład w postanowieniach art. 22 Konwencji w sprawie eliminacji wszelkich form dyskryminacji rasowej znajdujemy klauzulę sądową, umożliwiającą przekazanie sporu do Międzynarodowego Trybunału Sprawiedliwości. W 2008 roku Gruzja wykorzystała właśnie tę klauzulę w sporze z Federacją Rosyjską, składając skargę, w której oskarżyła ją o prowadzenie polityki czystek etnicznych na terytorium Gruzji w latach 1991-2008.W kwietniu 2011 roku MTS stwierdził, że nie ma kompetencji co do merytorycznego rozpatrzenia tej sprawy, ponieważ nie została wyczerpana procedura przewidziana w art. 22 Konwencji, przewidująca wcześniejsze wykorzystanie dyplomatycznych środków pokojowego regulowania sporów. Uznał więc za właściwe ewentualne rozstrzygnięcie sprawy w oparciu o postanowienia konwencji, a więc np. przy wykorzystaniu kompetencji CERD w zakresie skarg międzypaństwowych ${ }^{67}$.

W związku z tym należy wyjaśnić, że obok skarg międzypaństwowych składanych do organów traktatowych w systemie międzynarodowej ochrony praw człowieka występują niejako „klasyczne” skargi międzypaństwowe składane do organów sądowych w ramach procedury pokojowego regulowania sporów międzynarodowych. Najlepszym tego przykładem jest jurysdykcja międzynarodowego Trybunału Sprawiedliwości jako głównego organu stałego sądownictwa międzynarodowego. Jurysdykcja ta w sporach wyłącznie pomiędzy państwami jest co do zasady fakultatywna i opiera się na zgodzie państw-stron sporu. Poza kompromisem (zapisem na sąd) i klauzulą fakultatywną z art. 36 Statutu MTS zgoda taka może być oparta na klauzuli sądowej, która $z$ kolei może być zawarta również w umowach międzynarodowych z zakresu ochrony praw człowieka ${ }^{68}$. Przykład takiej sytuacji stanowi skarga Chorwacji przeciwko Serbii oparta na takiej klauzuli zawartej w art. IX Konwencji o zapobieganiu i karaniu zbrodni ludobójstwa z 1948 roku ${ }^{69}$.

$\mathrm{W}$ traktatowych systemach międzynarodowej ochrony praw człowieka $\mathrm{w}$ ramach ONZ znajduje się również instytucja niezależnego śledztwa (inquiries). Procedura ta realizowana jest w ramach CAT, CEDAW oraz CRPD. Dla przykładu, zgodnie z po-

$67 \mathrm{Na}$ temat tego sporu vid. np. M. Balcerzak, Spór gruzińsko-rosyjski przed sadami międzynarodowymi, [w:] Bezpieczeństwo międzynarodowe. Szanse i zagrożenia, red. S. Sykuna, J. Zajadło, Gdańsk 2011, s. 11-26.

$68 \mathrm{~Np}$. klauzula sądowa sformułowana w art. IX Konwencji o zapobieganiu i karaniu zbrodni ludobójstwa z 9 grudnia 1948 r., UNTS 78:277, tekst polski vid. Dz. U. 1952, Nr 2, poz. 9.

$69 \mathrm{Na}$ temat tej sprawy patrz dokumentacja MTS: http://www.icj-cij.org/. 
stanowieniami art. 20 Konwencji przeciwko torturom i innemu okrutnemu, nieludzkiemu lub poniżającemu traktowaniu lub karaniu, procedura ta polega na przeprowadzeniu przez CAT natychmiastowego, poufnego śledztwa, jeżeli Komitet otrzyma wiarygodne informacje o systematycznym stosowaniu tortur na terytorium danego państwa. Mechanizm takiego śledztwa ma charakter tak zwanego opt-out, a więc wiąże państwo od momentu ratyfikacji konwencji, chyba że zgodnie z postanowieniami art. 28 państwo wykluczyło stosowanie tej instytucji ${ }^{70}$.

\section{Organy traktatowe w procesie implementacji norm międzynarodowego prawa praw człowieka w systemie Rady Europy}

\section{System Konwencji o Ochronie Praw Człowieka i Podstawowych Wolności}

Konwencja o Ochronie Praw Człowieka i Podstawowych Wolności, w której określony został szeroki katalog praw obywatelskich i politycznych, stworzyła własny, bardzo charakterystyczny i skuteczny system kontrolny. Według pierwotnych postanowień Konwencji funkcje kontrolne wykonywały trzy instytucje: utworzona w 1954 roku Europejska Komisja Praw Człowieka, utworzony w 1959 roku Europejski Trybunał Praw Człowieka i Komitet Ministrów Rady Europy. System ten uległ istotnej zmianie na mocy postanowień Protokołu 11 do Konwencji, dotyczącego przekształcenia ustanowionego przez nią mechanizmu kontrolnego. Został podpisany 11 maja 1994 roku, a wszedł w życie 1 listopada 1998 roku $^{71}$. Polska ratyfikowała ten Protokół 20 maja 1997 roku $^{72}$.

Najważniejsze postanowienia Protokołu dotyczą zniesienia Europejskiej Komisji Praw Człowieka oraz dotychczasowego Europejskiego Trybunału Praw Człowieka działającego w trybie sesyjnym. Ewolucja systemu kontrolnego Konwencji oznaczała też zmianę roli Komitetu Rady Ministrów, który nie realizuje już żadnych funkcji judykacyjnych, a jego aktualna rola w systemie Konwencji polega na nadzorowaniu procesu wykonywania wyroków Europejskiego Trybunału Praw Człowieka, jak również na możliwości występowania do Trybunału z wnioskiem o wydanie opinii doradczej ${ }^{73}$. Oznacza to, że aktualnie organem traktatowym w systemie Konwencji o Ochronie Praw Człowieka i Podstawowych Wolności jest Europejski Trybunał Praw Człowieka. Jego pozycja na tle zaprezentowanych wcześniej organów traktatowych w systemie Organizacji Narodów Zjednoczonych jest zdecydowanie inna - to organ traktatowy o charak-

70 Wiele państw złożyło takie zastrzeżenie, w tym również Polska; dane vid. https://treaties. un.org/.

71 Tekst Protokołu: ETS No. 155.

72 Tekst polski vid. Dz. U. 1998, Nr 147, poz. 962.

73 Reformę systemu kontrolnego Konwencji referuje m. in. M. Balcerzak, op. cit., s. 170 i nast. 
terze sądowym, który może rozpatrywać dwa rodzaje skarg: skargi indywidualne i skargi międzypaństwowe ${ }^{74}$.

Jurysdykcję Trybunału określają postanowienia art. 32 Konwencji, zgodnie z którym Trybunał jest właściwy do rozpoznania wszystkich spraw dotyczących interpretacji i stosowania Konwencji i jej protokołów przedłożonych mu na podstawie artykułów 33, 34 i 475. Art. 33-34 określają w związku z tym dwa rodzaje skarg: skargi międzypaństwowe i skargi indywidualne. Kontynuacją procesu reformy systemu skargowego Konwencji, zwłaszcza w zakresie procedury rozpatrywania skarg przez Trybunał, są dwa najnowsze Protokoły, a mianowicie Protokół 14 i Protokół 14 bis. Zmieniają one system kontrolny Konwencji w kierunku ułatwienia i uproszczenia procedury rozpatrywania skarg ${ }^{76}$.

Warto przy tej okazji nadmienić, że najważniejsze propozycje odnośnie do kierunków rozwoju Europejskiego Trybunału Praw Człowieka zostały określone w Deklaracji z Izmiru stanowiącej rezultat konferencji zwołanej z inicjatywy Komitetu Ministrów Rady Europy w dniach 26-27 listopada 2011 roku. W deklaracji tej znajdujemy bardzo wyraźne odniesienie do tradycyjnej zasady rządzącej systemem ochrony praw człowieka w Radzie Europy, a więc zasady subsydiarności, jak również do działań na rzecz udoskonalenia systemu kontrolnego Konwencji, których przykładem są oba wskazane wyżej protokoły ${ }^{77}$.

\section{System Europejskiej Karty Społecznej}

Europejska Karta Społeczna stworzyła własny system kontrolny, który przeszedł wyraźną ewolucję. Pierwotny jego kształt określają postanowienia części IV Karty z 1961 roku (art. 21-29). Przepisy te tworzą mechanizm nadzoru nad przestrzeganiem postanowień Karty. Przewidują one sprawozdania państw oraz określają status Komitetu Ekspertów jako organu kontrolnego ${ }^{78}$. Swoje wnioski ze sprawowania kontroli nad stosowaniem przepisów Karty Komitet miał przedstawiać specjalnemu Komitetowi Rządowemu. Ten z kolei powinien przedkładać raporty Komitetowi Rady Ministrów Rady Europy wraz z propozycją zaleceń dla państw w jego opinii nieprzestrzegających postanowień Karty.

74 O reformie systemu kontrolnego Konwencji pisze np. M. A. Nowicki, Reforma systemu kontroli przestrzegania Europejskiej Konwencji Praw Cztowieka, [w:] „Biuletyn Centrum Europejskiego Uniwersytetu Warszawskiego" nr 3-4, 1998.

75 Ten ostatni przepis dotyczy opinii doradczych.

76 Protokół 14 - podpisany 13 maja 2004 r., wszedł w życie 1 czerwca 2010 r., tekst vid. ETS 194. Polska ratyfikowała ten Protokół 12 października 2006 r. Protokół 14 bis - podpisany 27 maja 2009 r., wszedł w życie 1 października 2009 r., tekst vid. ETS 204. Polska do tej pory go nie ratyfikowała.

77 Szeroko pisze o tych sprawach B. Gronowska, Europejski Trybunat Praw Cztowieka. W poszukiwaniu efektywnej ochrony praw jednostki, Torun 2011.

78 Aktualna nazwa: Europejski Komitet Praw Społecznych. 
Tak określony tryb nadzoru nad przestrzeganiem postanowień Karty modyfikuje dalej Protokół Zmieniający z 1991 roku. Zmienia on nazwę organu traktatowego Karty - Komitetu Ekspertów na Komitet Niezależnych Ekspertów - zwiększając liczbę jego członków i przyznając mu wyłączne prawo interpretowania i stosowania przepisów Karty. Ponadto rozszerza kompetencje Komitetu poprzez przyznanie mu prawa bezpośredniego zwracania się do władz państw członkowskich Rady Europy z żądaniem przedstawienia odpowiednich informacji. Protokół upoważnia też Komitet i jego prezydium do odbywania spotkań z przedstawicielami władz państw członkowskich lub grupami regionalnymi tych państw, a ponadto umożliwia udział organizacji reprezentujących partnerów społecznych w pracach Komitetu Rządowego. Zmniejszył też rolę Zgromadzenia Parlamentarnego i innych instytucji Rady Europy w procesie nadzoru nad stosowaniem postanowień Karty ${ }^{79}$.

Najbardziej istotną modyfikację systemu kontrolnego Europejskiej Karty Społecznej wprowadził Protokół Dodatkowy z 1995 roku. Pierwszorzędną i najbardziej rozpoznawalną jego cechą jest to, że wprowadził on do systemu kontrolnego Karty instytucję skarg zbiorowych (réclamations collectives, collective complaints). Warto jednak pamiętać, że tym samym Protokól przyznał międzynarodowym i krajowym organizacjom pracodawców i pracowników oraz określonym organizacjom pozarządowym prawo wnoszenia skarg na państwa członkowskie Rady Europy - strony Karty i Protokołu - w sytuacjach niezgodnego z przyjętymi standardami wykonywania przez nie przyjętych zobowiązań. Niektórzy Autorzy podkreślają w związku z tym, że wyposażając Komitet - organ traktatowy Karty w kompetencje do rozpatrywania skarg zbiorowych i przewidując w tej mierze określoną procedurę - Protokół upodobnił Komitet do organu o charakterze quasi-sądowym ${ }^{80}$.

Odpowiednie przepisy w zakresie systemu kontrolnego formułuje też Zrewidowana Europejska Karta Społeczna. Są to postanowienia jej części IV (art. C i D). Chociaż Karta ta stanowi istotne novum w warstwie materialno-prawnej, to w zakresie procedury kontrolnej stosują się do niej instytucje i mechanizmy wypracowane wcześniej, a więc zwłaszcza postanowienia Karty z 1961 roku i Protokołu Dodatkowego z 1995 roku.

79 Szerzej o tym Protokole vid. np. A. Świątkowski, op. cit., s. 39-40.

80 Tak piszą np. A. Brillat, op. cit., s. 52 i nast. oraz M. Jager, The Additional Protocol to the European Social Charter Providing for a System of Collective Complaints, [w:] „Leyden Journal of International Law" nr 10, 1997, s. 69 i nast., a z autorów polskich A. Świątkowski, Quasi-jurysdykcyjna funkcja Komitetu Praw Spotecznych Rady Europy, [w:] „Państwo i Prawo” nr 9, 2004, s. 46 i nast. 


\section{Europejski Komitet Praw Społecznych}

\section{Geneza i podstawy prawne}

W systemie kontrolnym obu Europejskich Kart Społecznych i Protokołów najważniejsze miejsce zajmuje organ traktatowy, jakim jest Europejski Komitet Praw Społecznych. Mając na względzie zaprezentowane wcześniej rozważania na temat organów traktatowych międzynarodowej kontroli praw człowieka w systemie ONZ, można powiedzieć, że w pewnym sensie jest on odpowiednikiem Komitetu Praw Gospodarczych, Społecznych i Kulturalnych w systemie Międzynarodowego Paktu Praw Gospodarczych, Społecznych i Kulturalnych. Idąc dalej i w pewnym uproszczeniu można też stwierdzić, $\dot{z}$ e - $\mathrm{z}$ uwagi na swoje quasi-sądownicze funkcje - jest on odpowiednikiem Europejskiego Trybunału Praw Człowieka w systemie Konwencji o Ochronie Praw Człowieka i Podstawowych Wolności. Pierwotną podstawą traktatową dla funkcjonowania tego Komitetu był art. 25 Europejskiej Karty Socjalnej, na mocy którego powstał Komitet Ekspertów (Comité d'experts) Protokół Zmieniający z 1991 roku zmodyfikował treść art. 25 Karty i zmienił nazwę Komitetu na Komitet Niezależnych Ekspertów (Comité d'experts indépendants), jednocześnie powiększając liczbę jego członków ${ }^{81}$. Wreszcie w 1998 r. Komitet zmienił swoją nazwę na aktualną: Europejski Komitet Praw Społecznych (Le Comité européen des Droits sociaux) ${ }^{82}$. Postanowienia te stanowią więc podstawę traktatową funkcjonowania Komitetu. Poza nimi ten organ traktatowy ma też swoją podstawę regulaminową dotyczącą bieżącego funkcjonowania. Jest nią Regulamin uchwalony przez Komitet 29 marca 2004 roku i zmodyfikowany 12 maja 2005 roku, 20 lutego 2009 roku i 10 maja 2011 roku $^{83}$.

\section{Skład i struktura organizacyjna}

W pierwotnej wersji art. 25 Europejskiej Karty Społecznej liczba członków Komitetu została określona jako nie mniej niż siedmiu. Protokół Zmieniający z 1991 roku ustalił tę liczbę na przynajmniej dziewięciu. Aktualnie, zgodnie z decyzją Komitetu Ministrów Rady Europy podjętą na 751 sesji w dniach 2-7 maja 2001 roku, na podstawie mandatu zawartego w art. 3 Protokołu Zmieniającego, liczba członków Europejskiego Komitetu Spraw Społecznych wynosi piętnastu. Kandydaci rekomendowani przez państwa członkowskie Rady Europy muszą być, jak stanowi art. 3 Protokołu Zmieniającego ustalający nową treść art. 25 Europejskiej Karty Społecznej, ekspertami „o najwyższej uczciwości i uznanej kompetencji w zakresie krajowych i międzynarodowych problemów socjalnych". Członkowie Komitetu - rekomendowani przez państwa - zasiadają w nim

81 Art. 3 Protokołu Zmieniającego z 1991 r.

82 Szczególowo pisze o tym A. Świątkowski, op. cit., s.38.

83 Regulamin, który został uchwalony 29 marca 2004 r. został następnie dwukrotnie zmodyfikowany: 12 maja 2005 r., 20 lutego 2010 r. i 10 maja 2011 r., http://hub.coe.int/. 
we własnym imieniu. W czasie sprawowania swojego mandatu nie mogą pełnić żadnej funkcji, której nie dałoby się pogodzić z wymogami niezawisłości, bezstronności oraz dyspozycyjności właściwymi dla ich działalności w Komitecie. Pomimo, że wspomniany wyżej art. 3 przewiduje wybór członków Komitetu przez Zgromadzenie Parlamentarne Rady Europy, z uwagi na fakt, iż Protokół Zmieniający jeszcze nie wszedł w życie, członkowie Komitetu wybierani są przez Komitet Ministrów, zgodnie z pierwotnym brzmieniem art. 25 Europejskiej Karty Społecznej. Kadencja członka Komitetu trwa sześć lat z możliwością jednorazowego powtórzenia wyboru. W aktualnym składzie Komitetu jest dr Marcin Wujczyk z Wydziału Prawa i Administracji Uniwersytetu Jagiellońskiego. Zajął on w Komitecie miejsce Profesora Andrzeja Świątkowskiego, który był członkiem Komitetu od 2003 roku do 1 stycznia 2013 roku.

Pracami Komitetu kieruje przewodniczący - aktualnie Luis Jimena Quesada, profesor Wydziału Prawa Uniwersytetu w Walencji. W skład kierownictwa Komitetu wchodzą ponadto: wiceprzewodniczący, którymi są aktualnie: Monika Schlachter (Niemcy) i Petros Stangos (Grecja) oraz Specjalny Sprawozdawca - Colm O’Cinneide (Irlandia). Wszyscy oni tworzą Biuro Komitetu. Komitet pracuje na sesjach w Strasburgu. Na rok 2014 zaplanowanych zostało 7 kilkudniowych sesji (podobnie jak w latach 2012 i 2013) ${ }^{84}$.

\section{Kompetencje}

Gdyby chcieć w sposób najbardziej ogólny, a zarazem trafny określić kompetencje Europejskiego Komitetu Praw Społecznych jako organu traktatowego Rady Europy w dziedzinie ochrony praw człowieka, to należałoby powiedzieć, że Komitet nadzoruje przestrzeganie przez państwa członkowskie tej organizacji postanowień traktatowych, stanowiących system Europejskiej Karty Społecznej. W ramach tak ogólnie określonych kompetencji Europejski Komitet Praw Społecznych:

- ustanawia europejskie standardy w zakresie prawa pracy, zabezpieczenia społecznego i polityki społecznej,

- analizuje sprawozdania przygotowane i przekazane przez państwa i orzeka o zgodności lub niezgodności przepisów krajowych ze standardami ustanawianymi na podstawie traktatów stanowiących system Europejskiej Karty Społecznej, a następnie formułuje pozbawione mocy prawnie wiążącej konkluzje (conclusions) przekazywane do Komitetu Rządowego, a stamtąd do Komitetu Ministrów Rady Europy ${ }^{85}$

- rozpoznaje skargi zbiorowe wnoszone przez uprawnione podmioty przeciwko państwom naruszającym zobowiązania przyjęte w systemie Karty, przygotowując końcowy raport w sprawie danej skargi, na podstawie którego Komitet Ministrów Rady Europy uchwala odpowiednią rezolucję lub rekomendację.

84 Wszystkie dane dostępne na stronie: http://hub.coe.int/.

85 Sprawozdania państw i procedurę ich rozpatrywania zaprezentuję w następnym punkcie. 
Analizowanie sprawozdań państw oraz rozpatrywanie skarg upodabniają Europejski Komitet Praw Społecznych do innych organów traktatowych w procesie implementacji norm międzynarodowego prawa praw człowieka. $Z$ drugiej jednak strony status Komitetu na tle innych organów traktatowych jest szczególny, jako że w ramach procedury rozpatrywania skarg zbiorowych upodabnia się on do organu sądowego, choć takim nie jest.

\section{System kontrolny Europejskiego Komitetu Praw Społecznych}

\section{Sprawozdania państw}

Jak już podkreślano, w przypadku wszystkich organów traktatowych ONZ funkcjonujących na podstawie szczegółowych konwencji międzynarodowego prawa praw człowieka wykorzystywana jest instytucja sprawozdań państw-stron tych konwencji, przekazywanych poszczególnym organom traktatowym. Są one też od początku obecne w systemie kontrolnym Europejskiej Karty Społecznej. Do czasu jego zasadniczej modyfikacji na podstawie postanowień Protokołu Dodatkowego z 1995 roku, wprowadzającego instytucję skargi zbiorowej, był on oparty na klasycznej instytucji sprawozdań.

Państwa-strony Karty mają więc obowiązek składania dwojakiego rodzaju sprawozdań związanych z zakresem przyjętych przez nie zobowiązań w ramach Karty. Jak wspomniano, zakres zobowiązań przyjętych przez poszczególne państwa w ramach Karty może być różny („hard core provisions” $i$ „non-hard core provisions”) ${ }^{86}$. Po pierwsze więc, na podstawie art. 21 Karty, państwa składają sprawozdania z realizacji ratyfikowanych jej postanowień. Po drugie natomiast, na podstawie art. 22, składają one sprawozdania $\mathrm{z}$ realizacji postanowień, którymi się nie związały w procedurze ratyfikacyjnej. Ponadto należy zauważyć, że na podstawie postanowień art. C Zrewidowanej Europejskiej Karty Społecznej ten mechanizm kontrolny ma zastosowanie również w procesie kontroli wykonywania przez państwa zobowiązań przyjętych przez nie w ramach Karty Zrewidowanej w zakresie, w jakim te zobowiązania przyjęły.

$\mathrm{Na}$ podstawie postanowień art. 21 państwa-strony są zobowiązane do składania wymaganych sprawozdań w odstępach dwuletnich na ręce Sekretarza Generalnego Rady Europy, który przekazuje je Komitetowi. Kopie sprawozdań są przesyłane przez państwa również krajowym organizacjom pracodawców oraz pracobiorców i mogą one zgłaszać do nich uwagi. Badanie oraz merytoryczną ocenę sprawozdań przeprowadza Komitet, w którego obradach bierze udział z głosem doradczym obserwator Międzynarodowej Organizacji Pracy. Formułując ocenę prawną sprawozdania, Komitet niekiedy odwołuje

86 Inaczej niż np. Konwencja o Ochronie Praw Człowieka i Podstawowych Wolności, która musi być przyjęta w całości. 
się do orzecznictwa Europejskiego Trybunału Praw Człowieka ${ }^{87}$. Pamiętać bowiem trzeba, że niektóre prawa i wolności, jak na przykład wolność zrzeszania się, są gwarantowane zarówno w Karcie, jak i w Konwencji o Ochronie Praw Człowieka i Podstawowych Wolności. Swoją ocenę prawną sprawozdań Europejski Komitet Praw Społecznych formułuje w formie konkluzji, które są przekazywane do Komitetu Rządowego, jako politycznego organu doradczego Komitetu Ministrów Rady Europy ${ }^{88}$. Ten organ bada treść konkluzji, zwłaszcza w części sygnalizującej naruszenie przez państwo postanowień Karty. W procesie takiego badania uczestniczą z głosem doradczym zaproszeni partnerzy społeczni - przedstawiciele międzynarodowych organizacji związków zawodowych. Efektem prac Komitetu Rządowego jest sprawozdanie dla Komitetu Ministrów Rady Europy, który z kolei uchwala rezolucję, uwzględniającą dokonania i oceny obu tych organów, a zawierającą indywidualne zalecenia pod adresem konkretnego państwa ${ }^{89}$.Zalecenia takie nie mają mocy prawnie wiążącej.

Omawiając procedurę przedkładania i badania sprawozdań należy pamiętać, ze pewną rolę w realizacji tego procesu odgrywa również Zgromadzenie Parlamentarne Rady Europy. Otrzymuje ono bowiem także konkluzje Europejskiego Komitetu Praw Społecznych z badanych przez niego sprawozdań państw, które wykorzystuje w czasie debat na temat polityki społecznej. Wypracowywane w czasie takich debat stanowisko jest kierowane do Komitetu Rady Ministrów Rady Europy uchwalającego wspomniane wyżej zalecenia pod adresem państw. Na podstawie postanowień art. 22 Karty Komitet Ministrów może zażądać od władz państw-stron przedstawienia sprawozdania na temat zależności pomiędzy regulacjami krajowymi i praktyką ich stosowania z tymi postanowieniami Karty, które nie zostały przez dane państwo przyjęte. Kopie sprawozdań są przekazywane również podmiotom wchodzącym w skład międzynarodowych organizacji partnerów społecznych, a zwłaszcza organizacjom pozarządowym mającym status doradczy przy Radzie Europy i prawo przedstawiania Sekretarzowi Generalnemu Rady swoich uwag. Procedurę rozpatrywania takich sprawozdań regulują postanowienia art. 24 i następne Karty.

\section{Skargi zbiorowe}

Podczas opisywania rozwoju regulacji prawnych międzynarodowego prawa praw człowieka zwrócono uwagę na dwutorowość tego procesu wynikającą zwłaszcza z historycz-

87 Pisze o tym szerzej T. Jasudowicz, Prawa rodziny - prawa w rodzinie w systemie Europejskiej Karty Spotecznej. Orzecznictwo Komitetu Niezależnych Ekspertów, Torun 1999, s. 8 i n.

88 W skład Komitetu Rządowego wchodzą przedstawiciele państw-stron Karty. Każde z nich ma w Komitecie jednego przedstawiciela, reprezentującego resort właściwy do spraw pracy i polityki społecznej. Państwa, które podpisały Kartę, ale jej nie ratyfikowały mogą wysyłać obserwatorów na posiedzenia Komitetu.

89 Podstawę rezolucji znajdujemy w postanowieniach art. 28 § 1 Karty w brzmieniu przyjętym w art. $5 \S 1$ Protokołu zmieniającego z $1991 \mathrm{r}$. O tej procedurze vid. np. S. Topa, Polska a konwencje Rady Europy, [w:] Rocznik Polskiej Polityki Zagranicznej 1997, red. B. Wizimirska, s. 253 i n. 
nej przewagi praw politycznych nad prawami gospodarczymi i społecznymi. Powołano dwie tendencje rozwojowe tych praw: double-track i double-speed widoczne nie tylko $\mathrm{w}$ ewolucji uniwersalnego systemu ochrony praw człowieka, ale również systemu europejskiego, a zwłaszcza systemu Rady Europy. Ta dwutorowość w rozwoju regulacji prawnych odnośnie do praw człowieka I i II generacji przeniosła się w systemie Rady Europy także na rozwój instrumentów i mechanizmów kontrolnych. W procesie implementacji postanowień Konwencji o Ochronie Praw Człowieka i Podstawowych Wolności przewidziano bardzo dobrze rozbudowany i skuteczny system skargowy z Europejskim Trybunałem Praw Człowieka jako organem o charakterze sądowym. Natomiast w procesie implementacji postanowień Europejskiej Karty Społecznej przewidziano pierwotnie tylko klasyczny system sprawozdań. Powstały oczywiste dysproporcje pomiędzy możliwością korygowania naruszeń przez państwa postanowień obu tych traktatów - z jednej strony przy użyciu metod skargowych przed organem sądowym, a z drugiej przy użyciu metod sprawozdawczych przed klasycznym organem traktatowym. Stąd też, aby w odpowiednim stopniu wyrównać poziom ochrony praw politycznych oraz praw gospodarczych i społecznych w systemie Rady Europy, wprowadzono do tego systemu instytucje i procedurę skargi zbiorowej. Stało się to za sprawą podpisanego w 1995 roku Protokołu Dodatkowego, który wszedł w życie w roku 1998. Przyznał on międzynarodowym i krajowym organizacjom pracodawców i pracowników oraz określonym organizacjom pozarządowym prawo wnoszenia skarg na państwa członkowskie Rady Europy - strony Karty i Protokołu - w sytuacjach niezgodnego z przyjętymi standardami wykonywania przez nie przyjętych zobowiązań.

\section{Uwagi końcowe}

Dorobek prawny Rady Europy w dziedzinie ochrony praw człowieka i podstawowych wolności jest bardzo bogaty, a stworzony przez tę organizację, na bazie traktatów wypracowanych pod jej egidą system kontrolny może być traktowany jako wzorcowy dla innych organizacji międzynarodowych. Zauważalną cechę systemu kontrolnego Rady Europy w zakresie praw człowieka stanowi jego niejednolitość. W swojej działalności Rada koncentrowała się pierwotnie na prawach politycznych i ich międzynarodowej ochronie. Problematyka ta została uregulowana w Konwencji o Ochronie Praw Człowieka i Podstawowych Wolności. Odpowiednikiem tej konwencji w dziedzinie ochrony praw ekonomicznych, społecznych i kulturalnych jest Europejska Karta Społeczna, a w zasadzie dwie Karty, które razem z Protokołami Dodatkowymi i Protokołem Zmieniającym tworzą cały system Europejskiej Karty Społecznej.

Europejska Karta Społeczna stworzyła własny system kontrolny w zakresie implementacji jej postanowień, a najważniejsza jego instytucja to Europejski Komitet Praw 
Społecznych. Gdyby chcieć w sposób najbardziej ogólny określić jego charakter prawny, należałoby powiedzieć, że Komitet ten jest jednym z organów traktatowych, jakie funkcjonują zarówno $\mathrm{w}$ uniwersalnym systemie międzynarodowej ochrony praw człowieka, jak również w systemach regionalnych. Podobnie jak inne organy traktatowe, Komitet realizuje klasyczne funkcje kontrolne, czyli rozpatruje sprawozdania państw-stron określonych traktatów międzynarodowego prawa praw człowieka. Jego pozycja w systemie tych organów jest jednak szczególna. Dysponuje on bowiem unikalnym instrumentem kontrolnym - skargami zbiorowymi, które znalazły się w systemie kontrolnym Europejskiej Karty Społecznej w wyniku znaczącej ewolucji tego systemu. Dokumentem dla niej przełomowym był Protokół Dodatkowy z 1995 roku. Istota i charakter skarg zbiorowych, które nie mieszczą się w ramach klasycznego podziału skarg składanych do organów traktatowych na skargi indywidualne i skargi międzypaństwowe, a zwłaszcza procedura ich rozpatrywania powodują, że Komitet pełni funkcję quasi-sądowego organu traktatowego.

\section{SUMMARY \\ The European Committee of Social Rights in the system of International Human Rights Treaty Bodies}

The aim of this article is to present the European Committee of Social Rights as a supervisory body in the system of international protection of human rights. To this end, the author elaborates upon the system of treaty bodies in the field of international protection of human rights, both at the universal level within the framework of the United Nations, as well as on the regional plain in respect of the treaty bodies within the Council of Europe's system. The author pays particular attention to the treaty acquis of the Council of Europe on the protection of social rights and, as such, discusses the European Social Charter system. The author emphasizes the particular role of a specific organ, namely the European Committee of Social Rights, within this field. One of its most notable features is the mechanism of collective complaints (fr. réclamations collectives), which was introduced to the Charter's supervisory system on the basis of the 1995 Additional Protocol. In the author's opinion, on the basis of the competence of the European Committee of Social Rights to hear collective complaints, it is arguable that this body performs the function of a quasi-judicial organ in the monitoring process, which distinguishes it from other treaty bodies in the field of international protection of human rights.

Keywords: international protection of human rights, human rights treaty bodies, European Social Charter system, European Committee of Social Rights, collective complaints. 
